\title{
ROZWÓJ GOSPODARKI CHIŃSKIEJ \\ W OKRESIE REALNEGO SOCJALIZMU - ANALIZA PODSTAWOWYCH WSKAŹNIKÓW MAKROEKONOMICZNYCH
}

Okres chińskiej gospodarki realnego socjalizmu ${ }^{1}$ cechował się wahaniami w wielkości produkcji i zmianami kierunków rozwoju w zależności od wprowadzanego planu gospodarczego. W ciagu niespełna 30 lat w gospodarce Chińskiej Republiki Ludowej (ChRL) można wyszczególnić sześć etapów:

- I plan pięcioletni (1952-1957),

- Wielki Skok (1958-1962),

- odbudowę po Wielkim Skoku (1963-1965),

- rewolucję kulturalną (1966-1970),

- IV plan pięcioletni (od końca 1970 do początku 1975 r.),

- okres trwający od ogłoszenia do rozpoczęcia wprowadzania programu „Czterech modernizacji” (1975-1978).

Nadrzędną idea przyświecającą Komunistycznej Partii Chin (KPCh) była rekonstrukcja gospodarki wyniszczonej po wojnach z Japonią i po wewnętrznych walkach cywilnych. Głównymi punktami strategii rozwoju proponowanej przez przewodniczącego KPCh Mao Zedonga stały się ścieżki regulacji kapitału i równości własności ziemi. W ten sposób zamierzano wyeliminować własność prywatną kapitalistów i właścicieli ziemskich.

Celem artykułu jest zaprezentowanie poszczególnych etapów rozwoju gospodarki Chin w okresie funkcjonowania systemu realnego socjalizmu. Jakościową analizę uzupełniono badaniem najważniejszych wskaźników makroekonomicznych. W artykule podjęto próbę odpowiedzi na pytanie, czy okres realnego socjalizmu skutkował progresem, czy regresem w rozwoju chińskiej gospodarki. Badaniu poddano mierniki rozwoju gospodarki z wyłączeniem kwestii związanych z międzynarodowymi stosunkami gospodarczymi, czyli relacjami handlowymi czy przepływem kapitału.

1 Przyjmuję, że okres realnego socjalizmu w Chinach zakończył się wraz z wprowadzaniem fundamentalnych reform od 1978 r. Szerzej: E. Cieślik, Rozwój gospodarcsy Chin od roku 1978 do krysysu globalnego, Warszawa 2015. 
Artykuł podzielono na trzy części. W pierwszej dokonano przeglądu najważniejszych reform i przekształceń w chińskiej gospodarce w okresie realnego socjalizmu. W drugiej przeanalizowano kształtowanie się najważniejszych wskániników obrazujących rozwój gospodarki Państwa Środka. W trzeciej skupiono się na czynnikach determinujących wzrost chińskiej gospodarki w okresie realnego socjalizmu.

Analiza przeprowadzona w artykule obejmuje lata 1949-1978, jednak w wyniku braku odpowiednich danych okres badawczy w wybranych przypadkach był skracany (najczęściej do lat 1952-1978). W celu uzyskania miarodajnych wyników badania wszystkie statystyki skorygowano o inflację. Ze względu na ograniczoną objętość artykułu zaprezentowany materiał ma charakter wstępu do pogłębionej analizy historii gospodarczej Chin po 1949 r.

\section{Przekształcenia i reformy chińskiej gospodarki w latach 1949-1978}

Od proklamacji ChRL w dniu 1 października 1949 r. do 1952 r. kraj w praktyce funkcjonował w oparciu o regulacje przejściowe, w ramach których prowadzono czystki personalne. Dążono do likwidacji spuścizny poprzedniego systemu. Przeprowadzono reformę rolną. Funkcjonowała własność mieszana². Rozbudowano aparat administracyjny. Usunięto urzędników związanych z poprzednią władzą - Kuomintangiem i warlordyzmem³. W celu walki z inflacją rząd przejął system bankowy. Utworzono stowarzyszenia handlowe, za pośrednictwem których nadzorowano poziom cen ${ }^{4}$. Połowę środków z budżetu przeznaczano na budownictwo ${ }^{5}$. Zapoczątkowano odbudowę szlaków transportowych ${ }^{6}$. Rekonstruowano żeglugę. $\mathrm{Na}$ szeroką skalę organizowano roboty publiczne. Chińską diasporę wzywano do powrotu do ojczyzny i inwestowania w kraju? W rezultacie nastapiło krótkotrwałe ożywienie w gospodarce.

Od 1952 r. gospodarka chińska funkcjonowała w oparciu o kolejne plany tworzone przez władze. I plan pięcioletni, ogłoszony jesienią 1952 r., odgrywał głównie rolę ideologiczną i nawiązywał do sowieckiej strategii rozwoju. Zapowiadał nacjo-

2 T.J. Huges, China's Economy - Retrospect and Prospect, „International Affairs” 1970, no. 1, s. 64.

3 O. Weggel, Chiny, Warszawa 2006, s. 79-80; E. Cieślik, Historia gospodarcza Chin okresu przedkomunistycznego. Przekesztatcenia wewnetrzne i miedzynarodowe stosunki gospodarcze, „Gdańskie Studia Azji Wschodniej” 2016, z. 10, s. 102-103.

4 J.K. Fairbank, Historia Chin. Nowe spojrzenie, Gdańsk 1996, s. 322.

5 R. Sławiński, Historia Chin i Tajwanu, Warszawa 2002, s. 87.

6 Do 1952 r. oddano do użytku 24,5 tys. km nowych linii kolejowych, 127 tys. km autostrad (57\% więcej niż w 1949 r.), długość szlaków wodnych zwiększono do ponad 95 tys. km (wzrost o 29\% od 1949 r.). Economy, China Handbook Editorial Committee, Beijing 1984, s. 12.

7 W okresie 1949-1952 do Chin napłynęło 80 tys. ludzi, w tym wielu uczonych i studentów. J. Polit, Historia Chin, Warszawa 2004, s. 195. 
nalizację przemysłu i kolektywizację rolnictwa ${ }^{8}$. W ramach planu PKB miał wzrastać rocznie w średnim tempie $8,9 \%$, produkcja przemysłowa $-18 \%$, a rolnicza $-4,5 \%$. Podczas realizacji pięciolatki w 1954 r. uchwalono Konstytucję ChRL, wzorowaną na ustawie zasadniczej ZSRR. Konstytucja wprowadziła do struktur państwa stanowisko przewodniczącego, które objął Mao Zedong ${ }^{10}$.

Bardziej szczegółowy okazał się II plan pięcioletni kładący nacisk na rozwój przemysłu ciężkiego. Jednak II plan pięcioletni wyrugowała strategia Wielkiego Skoku - kampania wprowadzana w ramach strategii ,trzech czerwonych sztandarów”11. W rzeczywistości program „trzech czerwonych sztandarów” zmierzał do osiagnięcia przyspieszonego tempa wzrostu w przemyśle ciężkim, czyli pod odmienną nazwą kontynuował założenia II planu pięcioletniego. Strategia Wielkiego Skoku zakładała przekształcenie ChRL w państwo realnego socjalizmu z nowoczesnym przemysłem, rolnictwem, życiem kulturalnym i zaawansowaną nauka. Miała zerwać z założeniami modelu sowieckiego, jednak w praktyce powieliła go, wprowadzając jedynie kilka modyfikacji polegających na zmianach w sposobie zarządzania i organizacji ${ }^{12}$. W zamierzeniu konstruktorów strategia miała równomiernie wkraczać do wszystkich dziedzin życia społeczno-gospodarczego. W procesie produkcji łączono techniki nowoczesne $z$ tradycyjnymi, lecz priorytet przyznano innowacyjnym rozwiązaniom. Obok siebie tworzono duże i małe przedsiębiorstwa, z naciskiem na duże fabryki. Integrowano sterowanie centralne $z$ lokalnym. Wiele z tych założeń było wewnętrznie sprzecznych i trudnych do pogodzenia ${ }^{13}$.

Wielki Skok zakładał podwojenie produkcji przemysłowej w ciagu roku poprzez zmobilizowanie chińskiej siły roboczej i kierowanie jej do produkcji przemysłowej. Realizowanie nierealnych planów produkcyjnych nakładanych przez władze na przemysł ciężki odbywało się kosztem rozwoju rolnictwa i przemysłu lekkiego. Poskutkowało to nierównościami w gospodarce. Rolnikom nakazywano porzucić gospodarstwa i kierowano ich do pracy przy wydobyciu surowców dla przemysłu ciężkiego oraz do budowy infrastruktury, co spowodowało spadek produkcji rolnej. Przemysłowi lekkiemu nie dostarczano odpowiednich surowców, a podaż podstawowych produktów żywnościowych nie zaspokajała popytu.

8 O. Weggel, Chiny ..., s. 259.

9 L. Fuchun, Report of the First Five-Year Plan, 1953-1957 [w:] Communist China, eds. R.R Bowie, J.K. Fairbank, Cambridge 1962, s. 42-91, za: K.E. Brodsgaard, Paradigmatic Change: Readjustment and Reform in the Chinese Economy, 1953-1981, Part I, „Modern China” 1983, no. 1, s. 43-44; J. Polit, Historia Chin ..., s. 205.

10 J.K. Fairbank, Historia Chin..., s. 322-324.

11 China's Third Five-Year Plan, „The China Quarterly” 1966, no. 25, s. 171.

12 W.J. Dziak, Chiny wschodzace supermocarstwo, Warszawa 1996, s. 11; R.F. Denberg, The People's Republic of Cbina At 50: The Economy, „The China Quarterly” 1999, no. 159, s. 607.

13 K. Gawlikowski, Wielki skok 1957-1960, maszynopis powielony 1976, s. 23, za: W.J. Dziak, Chiny wschodzace..., s. 14. 
Powoływano nowe przedsiębiorstwa przemysłu ciężkiego, które nie spełniały wymogów technologicznych, a ich produkty były niskiej jakości i często nie znajdowały nabywców ${ }^{14}$. Propagowano ideologię maoizmu, a osoba przewodniczącego stała się przedmiotem kultu, wzorem geniuszu i nieomylności ${ }^{15}$. Slogany łączenia pracy mięśni z wysiłkiem umysłowym wyznaczały obywatelom czas, jaki poświęcali na aktywność intelektualną i fizyczną ${ }^{16}$, a hasło „darmowej żywności” poskutkowało wzrostem konsumpcji i trudnościami w jej zaspokajaniu. Przekształcenia objęły również sądownictwo. Przyspieszono tryb wydawania orzeczeń i prowadzenia dochodzeń, co wywołało wzrost liczby aresztowanych i podporządkowanie stylu pracy wytycznym $\mathrm{KPCh}^{17}$.

Zgodnie z oficjalnymi danymi w latach 1958-1960 rozwinęło się szkolnictwo i poprawiła infrastruktura, głównie transportowa. Długość magistrali i linii kolejowych wzrosła z 24,5 tys. km w 1952 r. do 31,2 tys. w 1958 r. Waga przewożonych nimi produktów zwiększyła się ze $160 \mathrm{mln}$ ton do $380 \mathrm{mln}$ ton. Plan na rok następny zakładał wybudowanie 5,5 tys. $\mathrm{km}$ linii kolejowych i zwiększenie wagi przewożonych nimi towarów do $520 \mathrm{mln} \operatorname{ton}^{18}$. Pomimo wzmożonej propagandy oraz zawyżanych wskaźników ekonomicznych kampania Wielkiego Skoku napotykała na opór terenowych władz i działaczy partyjnych. Militaryzacja i ciąłe zwiększanie możliwości produkcyjnych w przemyśle ciężkim wyniszczały gospodarkę, prowadziły do marnotrawstwa, zaniku motywacji, zahamowały postęp i wydajność pracowników. Program odbudowy oświaty i nauki okazał się utopią. Liczba szkół wyższych zaczęła gwałtownie spadać. Brak wiedzy kierownictwa KPCh na temat realnej sytuacji kraju i konstruowane na podstawie sfałszowanych raportów ekonomicznych plany gospodarcze pogłębiały kryzys w Chinach ${ }^{19}$.

W strukturach partii wystapił rozłam. Po jednej stronie stali zwolennicy polityki „trzech czerwonych sztandarów”, po drugiej byli przeciwnicy reform, z marszałkiem Peng Dehuaim na czele, a pomiędzy nimi spora część niezdecydowanych towarzyszy partyjnych. Rozpoczęła się walka ideologiczna, która dotyczyła nie tylko obranej przez Chiny linii rozwoju, ale również sił zbrojnych. Z debaty zwycięsko wyszedł Mao, jednak krytyka Wielkiego Skoku przyćmiła blask wygranej. Wska-

14 R. Guo, How the Chinese Economy Works, New York 2007, s. 155, 285.

15 Chairman Mao Talks to the People, ed. S. Schram, New York 1974, za: S.W. Mosher, Hegemon. Droga Chin do dominacji, Warszawa 2007, s. 69.

16 Przykładem szerzenia idei równowagi między pracą fizyczną a umysłową były szpitale, w których osoby bez wykształcenia pełniły funkcje lekarzy, a lekarzy zsyłano na ciężkie prace budowlane czy do uprawy ziemi. China under Mao: Politics Takes Command. A Selection of Articles from the „China Quarterly”, London 1966, s. 16-17, za: W.J. Dziak, Chiny wschodzqce..., s. 19.

17 A. Spitz, Maoism and the People's Courts, „Asian Survey” 1969, no. 4, s. 255-263.

18 T. Shanbad, China's „Great Leap Forward”, „Far Eastern Survey” 1959, no. 7, s. 108-109.

19 Por. J. Rowiński, Polityka Chińskiej Republiki Ludowej wobec Indii w latach 1959-1963 (rozprawa doktorska), za: W.J. Dziak, Chiny wschodzqce..., s. 30-31. 
zane uchybienia prowadzonej polityki zmusiły do urealnienia następnych planów oraz powrotu do stosowania bodźców ekonomicznych, co oznaczało podważenie głównych założeń Wielkiego Skoku. Definitywny koniec strategii skokowej nastąpił w wyniku kryzysu agrarnego wywołanego klęską komun na wsiach i trzyletnim głodem. Spadek produkcji rolnej zahamował produkcję przemysłowa, prace inwestycyjne, wymusił likwidację wielu przedsiębiorstw, co pogłębiło bezrobocie ${ }^{20}$. Gospodarka została wytrącona z równowagi, a dysproporcje między sektorami potęgowały marnotrawstwo. W działach gospodarki z nadprodukcją zwiększały się zapasy, natomiast w pozostałych rodzajach działalności występowały niedobory materiałów ${ }^{21}$. Struktura gospodarki w ChRL konstruowana na podstawie decyzji politycznych była zupełnie oderwana od rynku.

Po 1960 r. próbowano odbudowywać gospodarkę Chin przez wprowadzenie nowych dyrektyw polityki rozwojowej. Nową linię partii określono mianem „regulacji, konsolidacji, wypełniania i podnoszenia standardu". Regulacja dotyczyła korekty w produkcji ${ }^{22}$, konsolidacja i wypełnienie miały zlikwidować nierentowne przedsiębiorstwa i wykorzystać dostępne moce produkcyjne, natomiast idea podnoszenia standardu zmierzała do poprawy jakości produktów. Odradzanie się gospodarki przerwała rewolucja kulturalna.

Okres rewolucji kulturalnej (1966-1970) ${ }^{23}$ zapisał się jako czas walk w aparacie władzy o utrzymanie dotychczasowego kursu polityki gospodarczej. Zamykano uczelnie i szkoły średnie, organizowano masowe wiece „edukujące” lud, prześladowano i represjonowano opozycję, a nawet mordowano niewygodnych działaczy ${ }^{24}$. Niszczono dziedzictwo kulturowe, naukę, sztukę, zmieniano nazwy ulic, placów i gmachów, likwidowano cały dotychczasowy dorobek gospodarczy przez powrót do kolektywizmu. Przepaść rozwojowa miedzy Chinami a krajami rozwiniętymi pogłębiała się.

Z końcem 1970 r. ogłoszono IV plan pięcioletni, którego założenia były tak bardzo nierealne, że już 2 lata później wprowadzono do niego poprawki ${ }^{25}$. Realizacja planu została przerwana w połowie 1975 r., kiedy przedstawiono w uproszczonej

\footnotetext{
20 Por. W.J. Dziak, Chiny wschodzace..., s. 48-51.

${ }^{21}$ K. Chao, Economic Aftermath of the Great Leap in Communist China, „Asian Survey” 1964, s. 852 .

${ }^{22}$ Korekta miała polegać na: osiaganiu wysokiego wskaźnika akumulacji w gospodarce, przy jednoczesnym spadku akumulacji w przemyśle ciężkim i wzroście tego indykatora w przemyśle lekkim, wyeliminowaniu wąskich gardeł i słabych linii produkcyjnych w przemyśle ciężkim i energetycznym. K.E. Brodsgaard, Paradigmatic Change..., s. 56-57.

${ }_{23}$ Rewolucja kulturalna trwała 3 lata, jednak wielu historyków podkreśla, że jej echa utrzymywały się całe dziesięciolecie - do 1976 r. J.K. Fairbank, Historia Chin..., s. 327; J. Polit, Historia Chin..., s. 248; J.W. Dziak, Chiny wschodrace..., s. 59.

${ }^{24}$ W. Rodziński, Historia Chin, Wrocław-Warszawa-Kraków 1974, s. 711.

25 http://www.gov.cn/english/2006-04/05/content_245708.htm (dostęp: 12.01.2009).
} 
formie program „Czterech modernizacji”. Propozycja nowej strategii, a następnie śmierć Mao Zedonga w 1976 r. położyły kres nieefektywnej polityce gospodarczej. Zaczął się proces wykorzeniania najbardziej wyrazistych zasad ideologii maoizmu, a gospodarka miała zostać poddana głębokiej modernizacji. Pod koniec 1978 r. władze Chin zdecydowały się na wprowadzanie strategii „Czterech modernizacji”, tym samym rozpoczęły transformację Państwa Środka w kierunku nowego systemu ekonomicznego.

\section{Poziom i dynamika rozwoju gospodarczego} według podstawowych wskaźników makroekonomicznych

Poniżej poddano analizie wybrane najważniejsze wskaźniki makroekonomiczne obrazujące zmiany w poziomie rozwoju Chin. Analizując kształtowanie się PKB i PKB per capita po 1952 r., widać trend wzrostowy, który jednak podlega wielu wahaniom. Największe spadki PKB notowano po Wielkim Skoku $(-18 \%$ w $1961 \mathrm{r}$ ) ) oraz w pierwszych latach rewolucji kulturalnej $(-3 \% \mathrm{w} 1967 \mathrm{r}$. i $-2,2 \%$ w 1968 r.). Tempo wzrostu PKB per capita było podobne. W okresie 1952-1978 realny PKB per capita Chin zwiększył się dwukrotnie z 334,23 USD do 667,82 USD, natomiast realny całkowity PKB wzrósł z ponad 192 mld USD do ponad 640 mld USD (wykres 1).

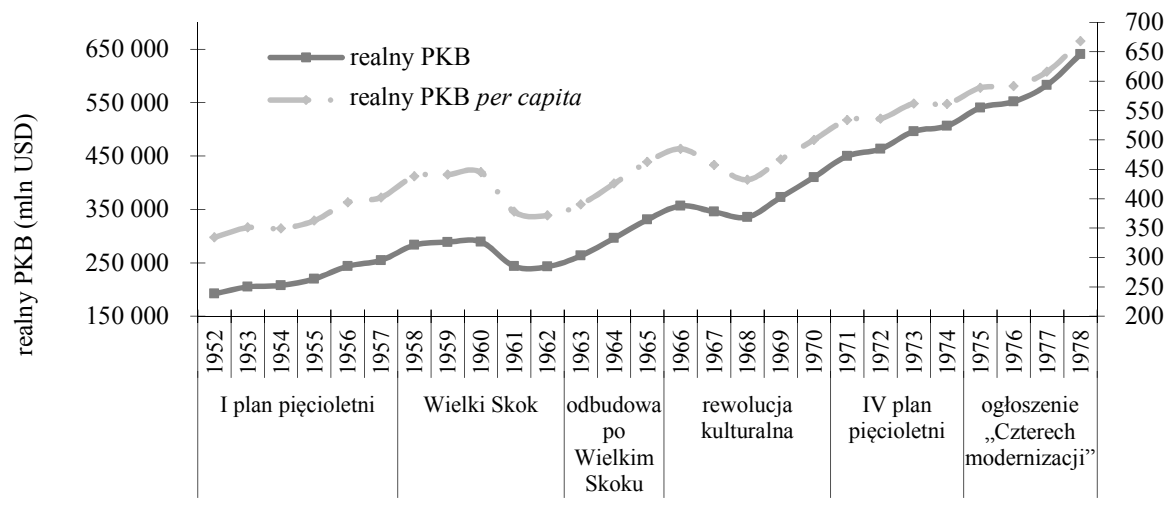

USD w cenach stałych z $2000 \mathrm{r}$.

Wykres 1. Kształtowanie się realnego PKB i PKB per capita w ChRL w latach 1952-1978

Źródło: obliczenia własne na podstawie danych Center for International Comparisons at the University of Pennsylvania, http://pwt.econ.upenn.edu/php_site/pwt62/pwt62_form.php (dostęp: 20.11.2016). 
Na poszczególnych etapach gospodarki planowej przeciętne wskaźniki wzrostu w przemyśle i budownictwie (sektor drugi gospodarki) przewyższały dynamikę wzrostu w pozostałych sektorach. Najwyższe przeciętne wzrosty produkcji w rolnictwie, przemyśle, budownictwie i usługach notowano w okresie odbudowy po Wielkim Skoku. Jednak wysokie tempo przyrostu produkcji nie utrzymało się długo - rewolucja kulturalna wyraźnie zahamowała dynamikę wzrostu we wszystkich sektorach. Największy spadek tempa wzrostu zanotowały usługi, natomiast najmniejsze zahamowanie dynamiki wzrostu obserwowano w przemyśle i budownictwie (tabela 1).

Tabela 1. Przeciętne tempo wzrostu produkcji rolnictwa, przemysłu i budownictwa oraz usług w latach 1952-1978

\begin{tabular}{|l|c|c|c|}
\hline \multicolumn{1}{|c|}{ Etapy chińskiej gospodarki } & $\begin{array}{c}\text { Rolnictwo } \\
{[\mathbf{\%}]}\end{array}$ & $\begin{array}{c}\text { Przemysł } \\
\text { i budownictwo } \\
{[\mathbf{\%}]}\end{array}$ & $\begin{array}{c}\text { Usługi } \\
{[\%]}\end{array}$ \\
\hline I plan pięcioletni (1952-1957) & 4,3 & 17,4 & 10,4 \\
\hline Wielki Skok (1958-1962) & $-1,5$ & 5,7 & $-0,7$ \\
\hline Odbudowa po Wielkim Skoku (1963-1965) & 16,6 & 22,9 & 15,5 \\
\hline Rewolucja kulturalna (1966-1970) & 4,7 & 11,6 & 4,2 \\
\hline IV plan pięcioletni (1971-1974) & 4,2 & 6,7 & 4,2 \\
\hline $\begin{array}{l}\text { Ogłoszenie „Czterech modernizacji” } \\
\text { (1975-1978) }\end{array}$ & 1,3 & 9,7 & 6,9 \\
\hline
\end{tabular}

Obliczenia przeprowadzano na RMB w cenach stałych z $1995 \mathrm{r}$.

Źródło: opracowanie i obliczenia własne na podstawie danych National Bureau of Statistics of China, http://www.stats.gov.cn/english/statisticaldata/yearlydata/ (dostęp: 20.11.2016); Y. Wang, Y. Yao, Sources of China's Economic Growth 1952-1999; Incorporating Human Capital Accumulation, „China Economic Review" 2003, no. 14, s. 49-50.

Analizując strukturę chińskiego PKB do 1978 r., obserwuje się stopniowe przechodzenie gospodarki przedindustrialnej w industrialna, zgodnie z podziałem faz rozwoju zaproponowanym przez D. Bella ${ }^{26}$. Rolnictwo odnotowało największy spadek udziału w chińskim PKB w okresie Wielkiego Skoku. Jeszcze w 1952 r. rolnictwo wytwarzało ponad połowę PKB, podczas gdy w 1960 r. jego udział spadł do 23,4\%. Na koniec 1978 r. sektor agrarny gospodarki tworzył 28,1\% chińskiego PKB. Podczas Wielkiego Skoku i w latach 70. XX wieku przemysł i budownictwo miały najwyższy odsetek w generowaniu chińskiego PKB, co w pierwszym ze wskazanych tu okresów odbywało się głównie kosztem rolnictwa. W latach 70. zwiększenie udziału sektora drugiego powodowało równomierny spadek w udziale usług i rolnictwa w strukturze PKB. W okresie maoizmu relatywnie niski odsetek PKB generowały usługi, które najwyższy wskaźnik udziału w PKB osiągnęły w 1960 r. (32,1\%) (wykres 2).

26 D. Bell, The Cultural Contradictions of Capitalism (Kulturalna sprzecznośc kapitalizmu), Archiwum Przekładów i Opracowań, Warszawa 1978, s. 251-265, 333. 


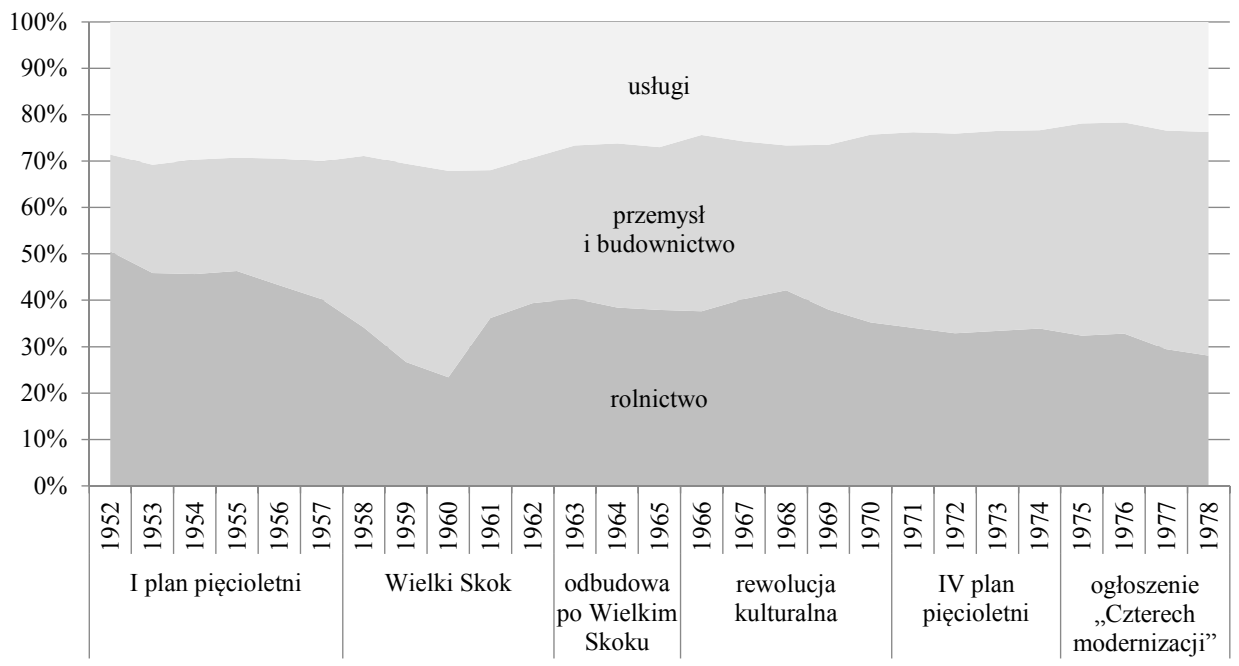

Wykres 2. Udział poszczególnych sektorów gospodarki w tworzeniu PKB w latach 19521978

Źródło: opracowanie własne na podstawie: Historical National Accounts of the People's Republic of China, 1952-1995, Institute Research of Hitotsubashi University, Tokyo 1997, tab. A.5.

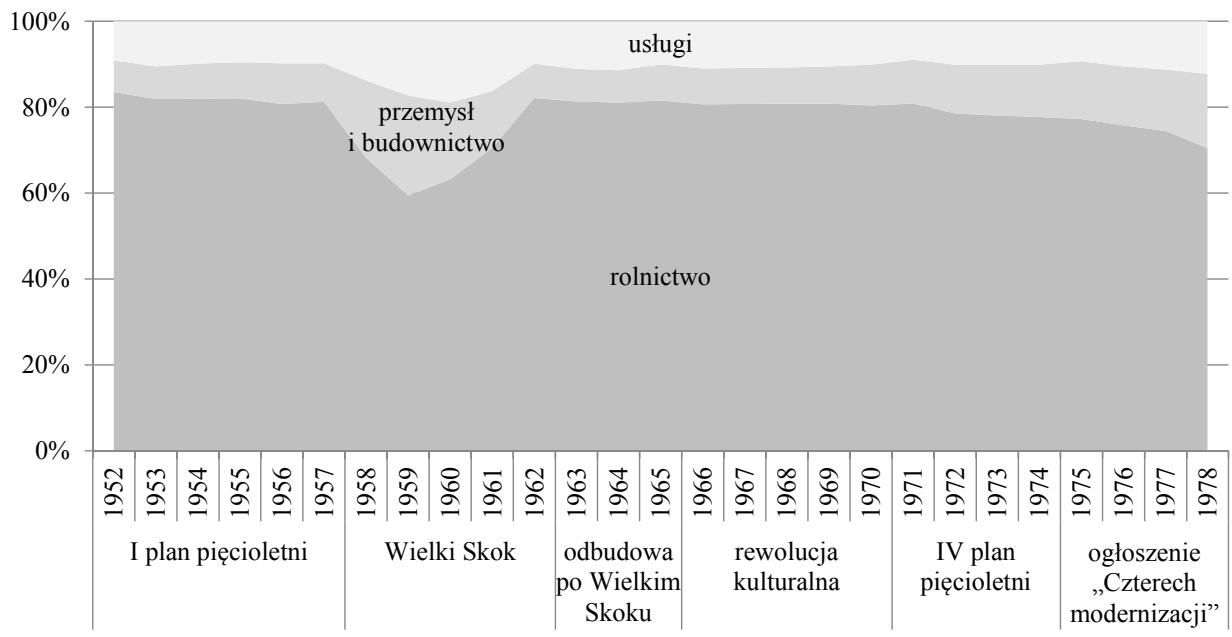

Wykres 3. Struktura zatrudnienia według sektorów gospodarki w latach 1952-1978

Źródło: opracowanie własne na podstawie: China Statistical Yearbook 1993, s. 78-79, za: A. Maddison, Chinese Economic Performance in the Long Run, Development Centre Studies of OECD, Paris 1998, s. 171; China Statistical Yearbook 2007, National Bureau of Statistics in China, China Statistics Press, no. 26, Beijing 2007, s. 130. 
W strukturze zatrudnienia ChRL zawsze dominowali pracujący w rolnictwie. W 1952 r. stanowili oni 82,5\% wszystkich zatrudnionych. Do okresu Wielkiego Skoku odsetek ten pozostawał wysoki. Dopiero strategie promujące rozwój przemysłu spowodowały spadek udziału zatrudnionych w rolnictwie. Na koniec 1978 r. sektor pierwszy zatrudniał niespełna $72 \%$ wszystkich pracujących, sektor drugi - 16\%, a trzeci - ponad $12 \%$. Wahania w strukturze zatrudnienia, podobnie jak fluktuacje w strukturze PKB, wynikały ze zmian kierunków polityki gospodarczej (wykres 3). W okresie 1952-1978 średni roczny przyrost zatrudnienia w rolnictwie wynosił $2 \%$, w sektorze drugim $-5,8 \%$, natomiast w usługach $-3,2 \%{ }^{27}$.

\section{Czynniki wzrostu gospodarczego ChRL do 1978 r.}

Analizując chińską gospodarkę okresu realnego socjalizmu, trudno pominąć czynniki determinujące wzrost ekonomiczny w kraju, m.in. produktywność pracy czy inwestycje krajowe.

Pomimo że przez cały badany okres najwięcej osób zatrudniało chińskie rolnictwo (wykres 3), to wydajność tych pracowników pozostawała najniższa wśród wszystkich zatrudnionych z podziałem na sektory. Ponadto efektywność pracujących w rolnictwie znacznie odbiegała od przeciętnej wydajności w całej gospodarce. Przykładowo, w 1952 r. przeciętny zatrudniony w rolnictwie wytwarzał rocznie produkty o wartości 304 USD, a do 1978 r. wartość ta zwiększyła się do $464 \mathrm{USD}^{28}$. W przypadku sektora drugiego obserwowano wahania wydajności pracowników - nagłe spadki wystapiły podczas Wielkiego Skoku i rewolucji kulturalnej, co świadczyło o tym, że w społeczeństwie brakowało bodźców zachęcających do efektywnej pracy, a także o destrukcji społecznej. W latach 1969-1978 pracownicy sektora przemysłowego i budownictwa pozostawali najbardziej wydajni spośród zatrudnionych w trzech sektorach. W 1978 r. przeciętny zatrudniony w przemyśle i budownictwie wytwarzał rocznie produkcję o wartości 2276 USD. Wydajność zatrudnionych w usługach, po znacznym spadku w okresie Wielkiego Skoku, od 1963 do 1970 r. cechowała się stabilnością i oscylowała wokół 1500 USD (wykres 4).

Na niską produktywność pracy w ChRL w badanym okresie niemały wpływ miało pogorszenie jakości siły roboczej. W wyniku niszczących kampanii ideologicznych, szczególnie rewolucji kulturalnej, znacząco spadła liczba wykwalifikowanej kadry.

\footnotetext{
27 A. Maddison, Chinese Economic Performance in the Long Run, Paris 1998, s. 68.

28 Produktywność zatrudnionego w chińskim rolnictwie w $1978 \mathrm{r}$. była ponad dwukrotnie niższa w porównaniu z produktywnością pracowników rolnych w USA. Ibidem, s. 112.
} 


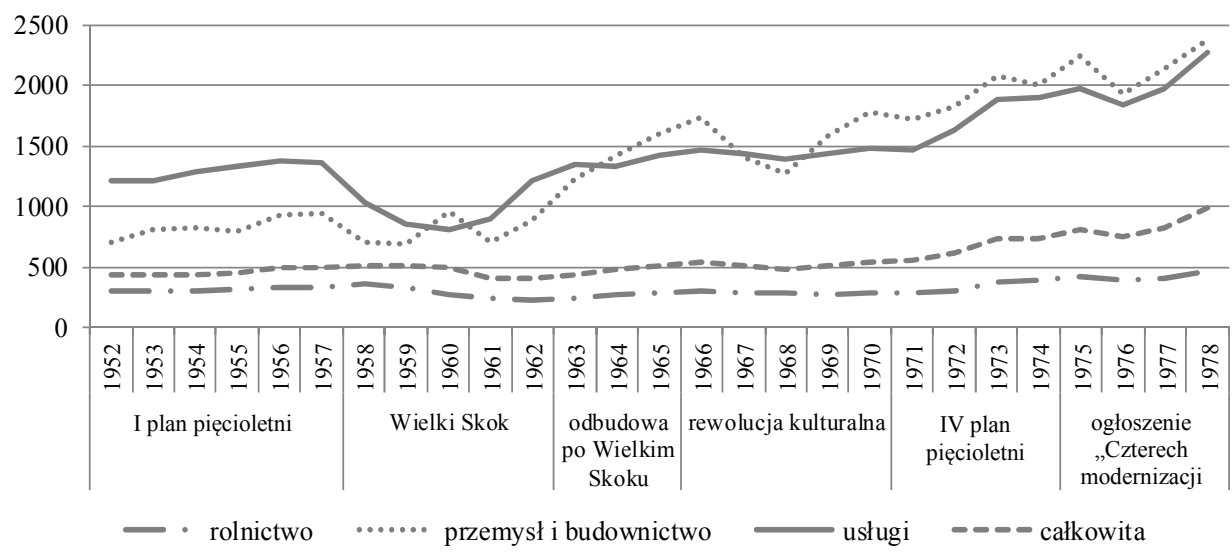

Produkcja każdego sektora wyrażona w cenach stałych z 1987 r. w przeliczeniu na USD

Wykres 4. Wydajność zatrudnionych w poszczególnych sektorach gospodarki i całej gospodarce w latach 1952-1978 (w USD na jednego zatrudnionego)

Źródło: opracowanie własne na podstawie: China Statistical Yearbook 1993, s. 78-79, za: A. Maddison, Chinese Economic Performance..., s. 171; China Statistical Yearbook 2007..., s. 130.

Jeszcze w 1965 r. odsetek inżynierów i techników sektora industrialnego wynosił 4\%, natomiast do 1976 r. spadł do poziomu 2,6\% $\%^{29}$.

Kolejnym czynnikiem stymulującym wzrost gospodarki chińskiej w badanym okresie były inwestycje. Wysoka wartość relacji przeprowadzonych inwestycji względem chińskiego PKB oraz wysoki poziom utrzymywanych zapasów w stosunku do PKB były typowymi cechami gospodarek realnego socjalizmu. Także władze ChRL, wzorując się na modelu gospodarki radzieckiej, ważną rolę przypisywały akumulacji kapitału. W tym celu propagowano ograniczoną konsumpcję, a płace utrzymywano na niskim poziomie. W okresie 1952-1977 Chiny ustępowały tylko Niemcom (lata 1952-1957) i Japonii (lata 1958-1977) we wskaźniku inwestycji brutto/PKB. Chińskie przedsiębiorstwa państwowe utrzymywały spore zapasy materiałów w celach inwestycyjnych i na wypadek zakłóceń w realizacji wyznaczonych planów. W latach 1971-1979 przedsiębiorstwa państwowe i spółdzielnie zainwestowały ponad $83 \mathrm{mld}$ RMB (około 33,7 mld USD) ${ }^{30}$. W okresie 1952-1977 Chiny notowały najwyższy udział zmian zapasów w PKB wśród analizowanych krajów (tabela 2). Można przypuszczać, że ze względu na regulowane ceny udział inwestycji brutto w PKB prawdopodobnie był jeszcze wyższy. Władze ChRL zaniżały ceny dóbr inwestycyjnych,

29 K. Seitz, Chiny. Powrót olbrayma, przeł. T. Mazur, Warszawa 2013, s. 195.

30 State Statistical Burean 1985, s. 36, 413, 420, 450, za: D.H. Perkins, Reforming China's Economic System, "Journal of Economic Literature" 1988, no. 2, s. 617. 
a utrzymywano wysokie ceny towarów konsumpcyjnych ${ }^{31}$. Większość inwestycji finansowało państwo.

Tabela 2. Zestawienie inwestycji dokonanych w Chinach i zmiany stanu zapasów w latach 1952-1977 z inwestycjami i zapasami wybranych krajów rozwiniętych (\%)

\begin{tabular}{|l|c|c|c|c|}
\hline \multirow{2}{*}{ Kraj } & \multicolumn{2}{|c|}{ Inwestycje brutto/PKB } & \multicolumn{2}{c|}{ Zmiany zapasów/PKB } \\
\cline { 2 - 5 } & $\mathbf{1 9 5 2 - 1 9 5 7}$ & $\mathbf{1 9 5 8 - 1 9 7 7}$ & $\mathbf{1 9 5 2 - 1 9 5 7}$ & $\mathbf{1 9 5 8 - 1 9 7 7}$ \\
\hline Chiny & 23,2 & $\mathbf{2 8 , 0}$ & 8,6 & 6,5 \\
\hline Japonia & 16,9 & 34,3 & 4,5 & 2,4 \\
\hline Francja & 18,8 & 25,2 & 1,5 & 1,8 \\
\hline Niemcy & 23,4 & 25,2 & 2,4 & 1,4 \\
\hline Wielka Brytania & 15,3 & 18,7 & 0,9 & 0,8 \\
\hline USA & 19,0 & 18,5 & 0,6 & 0,8 \\
\hline
\end{tabular}

Źródło: opracowanie własne na podstawie: A. Maddison, Chinese Economic Performance in the Long Run, Paris 1998, s. 64.

Czynniki kształtujące wzrost gospodarczy Chin w okresie maoizmu z różnym natężeniem wpływały na wzrost PKB. W latach 1953-1957 bezwzględnie siłą napędową wzrostu chińskiego produktu materialnego netto pozostawała produktywność czynników produkcji, natomiast najmniejszą rolę we wzroście gospodarczym odgrywał kapitał czy siła robocza. W okresie 1958-1966 relacje te zmieniły się - najważniejszą składową wzrostu gospodarczego stał się kapitał, natomiast wydajność, osiagając ujemne wartości, znacząco zaniżała wzrost ekonomiczny kraju. W latach 1966-1976 znaczenie kapitału dalej się umacniało i utrzymał on wiodąca pozycję w stymulowaniu wzrostu gospodarczego ChRL (tabela 3).

Tabela 3. Determinanty wzrostu gospodarczego ChRL w latach 1953-1976 (roczny procentowy wzrost w cenach stałych z 1980 r.)

\begin{tabular}{|l|c|c|c|}
\hline \multicolumn{1}{|c|}{$\begin{array}{c}\text { Determinanty wzrostu gospodarczego } \\
\text { w ChRL }\end{array}$} & 1953-1957 & 1958-1966 & 1966-1976 \\
\hline Wzrost kapitału & 0,84 & 1,87 & 2,81 \\
\hline Wzrost siły roboczej & 1,67 & 1,63 & 1,68 \\
\hline Wzrost wydajności & 4,10 & $-1,41$ & 0,62 \\
\hline Całkowity wzrost produktu materialnego netto & 6,61 & 2,09 & 5,11 \\
\hline
\end{tabular}

Źródło: D.H. Perkins, Reforming Cbina’s Economic System, „Journal of Economic Literature” 1988, no. 2, s. 628.

31 Na problem w obliczaniu poziomu niektórych wskaźników rozwoju Chin w związku z regulowanymi cenami wskazał również C. Bramall. C. Bramall, Chinese Economic Development, LondonNew York 2009, s. 291-292. 
Biorąc pod uwagę wysokie wskaźniki akumulacji kapitału (tabela 2), należałoby odpowiedzieć na pytanie, kiedy wysokie stopy inwestycji, a wręcz przeinwestowanie, negatywnie wpływały na pozostałe czynniki wzrostu. Takie powiązanie wynika bezpośrednio z tabeli 3 - wraz ze wzrostem kapitału spadały udziały wydajności. Jednak na podstawie poniższych danych trudno jednoznacznie wyrokować, czy przeinwestowanie miało wpływ na spadek wydajności. W celu jednoznacznej odpowiedzi na to pytanie należałoby przeprowadzić dokładną analizę sektorową.

\section{Wnioski}

ChRL w okresie adaptacji systemu gospodarki centralnie zarządzanej na wzór ZSRR cechowała się niskim wzrostem ekonomicznym i relatywną izolacją kraju na arenie międzynarodowej. Opierająca się na ideologii komunistycznej gospodarka była silnie scentralizowana, a alokacja czynników produkcji rzadko podlegała zasadom efektywności ekonomicznej, co powodowało znaczne dysproporcje w gospodarce. Ostatecznie Chiny klasyfikowano w 1978 r. wśród najuboższych państw świata.

Chociaż zaprezentowane wyżej podstawowe wskaźniki makroekonomiczne ukazują wzrost chińskiej gospodarki w okresie realnego socjalizmu (wykres 1, tabele 1 i 2), to nie zmieniała się znacząco struktura sektorowa gospodarki oraz zatrudnienie w poszczególnych działach produkcji (wykresy 2 i 3). Ponadto warto spojrzeć na postępy gospodarcze Państwa Środka w kontekście jego udziału w gospodarce światowej. Mimo że udział ChRL w światowej populacji nieznacznie wzrósł (jednak przyrost naturalny był bardzo wysoki), to pozycja ekonomiczna nie poprawiła się znacząco w latach 1949-1978, nie pomogły liczne reformy mające na celu stymulowanie produkcji. Udział Chin w światowym PKB w 1950 r. wynosił 4,5\%, a w 1978 r. wzrósł do 4,9\%. Dawało to ChRL piątą pozycję w rankingu światowym, za USA, ZSRR, Wielką Brytanią i Niemcami. Chińskie PKB per capita stanowiło w 1950 r. 21\% średniego światowego PKB na osobę, a do 1978 r. wzrosło tylko o $1,1 \%$. Rezultatem prowadzenia polityki samowystarczalności był niewielki $(0,8 \%)$ udział w światowym eksporcie. Podczas gdy wskaźniki określające pozycję ekonomiczną kraju spadały, ludność Chin w 1978 r. stanowiła aż 22,3\% populacji świata (w 1950 r. udział ten wynosił 21,7\%) (tabela 4).

Chcąc zachować obiektywizm w ocenie rezultatów lat realnego socjalizmu w ChRL, poza typowo ekonomicznymi wskaźnikami rozwoju okresu maoizmu należy wskazać wiele jakościowych zmian poziomu życia. Można zaobserwować progres, szczególnie w odniesieniu do okresu rewolucji kulturalnej. Przeciętna długość życia wzrosła z 34 lat w okresie 1950-1955 do 64 lat w 1978 r. ${ }^{32}$ Śmiertelność niemowląt spadła, poprawiły się warunki sanitarne i opieka zdrowotna. Zwiększyła

32 A. Maddison, Chinese Economic..., s. 61. 
Tabela 4. Pozycja ChRL w gospodarce światowej w latach 1950-1978

\begin{tabular}{|c|c|c|c|c|c|}
\hline 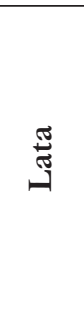 & 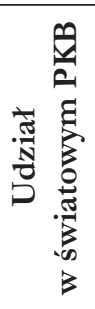 & 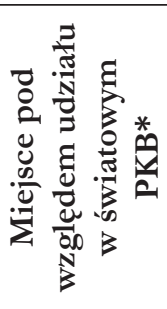 & 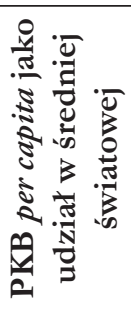 & 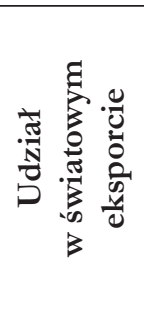 & 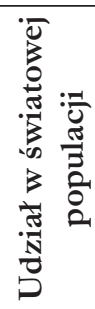 \\
\hline 1950 & $4,5 \%$ & 4 & $21,0 \%$ & $1,0 \%$ ** & $21,7 \%$ \\
\hline 1965 & $4,7 \%$ & 5 & $21,8 \%$ & - & $21,5 \%$ \\
\hline 1978 & $4,9 \%$ & 5 & $22,1 \%$ & $0,8 \%$ & $22,3 \%$ \\
\hline
\end{tabular}

* uwzględniając ZSRR; ** dane na 1952 r.

Źródło: obliczenia i opracowanie własne na podstawie: A. Maddison, The World Economy: Historical Statistics, Development Centre Studies of OECD, Paris 2003.

się liczba spożywanych kalorii oraz wyraźnie zredukowano analfabetyzm ${ }^{33}$. Do rewolucji kulturalnej liczba osób z wyższym wykształceniem sukcesywnie rosła ${ }^{34}$.

Negatywnym aspektem wprowadzanych reform okresu maoizmu był wzrost dysproporcji ekonomicznych w społeczeństwie chińskim. Współczynnik Giniego między 1952 a 1978 r. zwiększył się z 22,4\% do około 29,3\%. Najwyższe zróżnicowanie odnotowano w okresie Wielkiego Skoku: współczynnik Giniego w 1960 r. dochodził nawet do 32,5\% ${ }^{35}$. Pogłębiło się również rozwarstwienie w podziale administracyjnym (między prowincjami). W $1952 \mathrm{r}$. PKB przypadający na mieszkańca najuboższej wówczas prowincji Chin - Guizhou był prawie jedenastokrotnie niższy niż dochód per capita najbogatszej prowincji - Szanghaju. W 1980 r. luka między tymi dwiema prowincjami wyniosła prawie 1:28 ${ }^{36}$.

Między 1952 a 1978 r. zwiększyły się również dysproporcje między mieszkańcami wsi i miast. Przykładowo, w 1952 r. roczne przeciętne wydatki konsumpcyjne mieszkańca wsi były 2,4 raza mniejsze niż osoby zamieszkującej miasto. W $1978 \mathrm{r}$. relacja rocznych wydatków konsumpcyjnych mieszkańców wsi do rezydentów miast wynosiła 1:2,9. Jednak największe nierówności obserwowano w okresie Wielkiego Skoku, kiedy relacja wydatków konsumpcyjnych mieszkańców wsi i obszarów zurbanizowanych osiagnęła niemal poziom 1:3,237.

33 China. Strategies for Reducing Poverty in the 1990s, Washington D.C. 1992, s. 1.

34 A. Maddison, Chinese Economic..., s. 63-61.

35 R. Kanbur, X. Zhang, Fifty Years of Regional Inequality in China: A Journey Through Central Planning, Reform, and Openess, „Review of Development Economics” 2005, no. 9, s. 93.

36 R. Guo, How the Chinese..., s. 117.

37 D.T. Yang, C. Fang, The Political Economy of China's Rural-Urban Divide, Center for Research on Economic Development and Policy Reform, Stanford University, "Working Paper" 2000, no. 52, s. 32 . 
Podsumowując, mimo że okres gospodarki centralnie planowanej w Chinach przez wielu ekonomistów i historyków gospodarczych został oceniony jako destrukcyjny $^{38}$, to wskaźniki potencjału ekonomicznego i poziomu życia świadcza o wystapieniu zjawiska wzrostu, a nawet rozwoju w wybranych dziedzinach. W teorii stadiów wzrostu W.W. Rostowa maoizm mógłby zostać zakwalifikowany jako etap startu do rozwoju gospodarczego. Szczególnie rozwojowi Chin miały sprzyjać wysokie, w porównaniu z krajami rozwiniętymi, wskaźniki inwestycji. Jednak przeprowadzanym inwestycjom nie towarzyszyło równie wysokie tempo wzrostu wydajności pracowników, produktywności kapitału czy rozwój technologiczny. Okres maoizmu, pomimo wspomnianego wcześniej bardzo wysokiego wskaźnika akumulacji kapitału, można traktować tylko jako etap przygotowujący Państw Środka do wkroczenia na ścieżkę rozwoju społeczno-gospodarczego ${ }^{39}$. Pierwszym krokiem $\mathrm{ku}$ fundamentalnym zmianom systemowo-instytucjonalnym w ChRL były decyzje, które zapadły na III Plenum Komitetu Centralnego KPCh w grudniu 1978 r. Poskutkowały one wprowadzeniem reformatorskiego programu „Czterech modernizacji” "40, który objął przemysł, rolnictwo, obronę narodową, naukę i technikę.

\section{SUMMARY}

\section{THE DEVELOPMENT OF THE CHINESE ECONOMY \\ IN THE PERIOD OF REAL SOCIALISM: AN ANALYSIS OF BASIC MACROECONOMIC INDICATORS}

The main aim of the article is to present the different stages of China's economic development in the period of real socialism. This paper attempts to answer the question whether the period of real socialism resulted in a progress or regression in China's development. The study focuses on an overview of the most important reforms in Chinese economy during the period of real socialism. Then it analyzes the most important indicators of development. In the end, the article presents the factors of economic growth. The study covers the years 1949-1978, but due to the lack of appropriate data sometimes we have to shorten the research period. In order to obtain reliable results of the study, all statistics were adjusted to inflation.

38 B. Ashtone, K. Hiu, A. Piazza, R. Zeitz, Famine in China, 1958-61, „Population and Development Review" 1984, s. 613-645, za: D.N. Sull, Y. Wang, Made in China, Warszawa 2006, s. 36.

39 W.W. Rostow, The Stages of Economic Growth: A Non-communist Manifesto, Cambridge 1960, s. 6; W.W. Rostow, The Stages of Economic Growth, „The Economic History Review” 1959, no. 1 (12), s. $4-5$.

40 Cele programu wywodziły się w dużej mierze z pracy premiera Chou z 1964 r. Premier Hua 11 lat później (1975 r.) w swoim raporcie przedłożonym V Narodowemu Kongresowi Ludowemu uzupełnił wytyczne o hasło przyspieszenia modernizacji socjalistycznej. J.K. Kallgren, China 1978: The New Long March, „Asian Survey” 1979, no. 1, s. 12. 